\title{
Analysis of The Effect of Supervision, Job Relations, and Compensation on Job Satisfaction and its Impact on Job Performance in CV. Aliansyah Winong Pati
}

\author{
Mohammad Hidayat Mukrom \\ Agatha Ferijani \\ Soegijapranata Catholic University \\ dayatmister92@gmail.com, 082134587799
}

\begin{abstract}
This study aims at determining conditions of job satisfaction, job performance, supervision, job relations, and compensation in $C V$. Aliansyah Winong Pati; explaining the influence of supervision, job relations, and compensation on respectively job satisfaction and on job performance, and examining the effect of job satisfaction on job performance. The research is an explanatory with a quantitative approach in which the independent variables are supervision, job relations, and compensation. The dependent variable is job performance with job satisfaction as the mediator variable. The sample of this study was 78 employees of CV. Aliansyah Winong Pati. The data were primary and secondary data. The primary data were gathered by means of questionnaires. The secondary data were obtained from the company, journals, and previous research. Methods for analyzing data were descriptive analysis, regression, and path analysis. The results show that supervision, job relations, and compensation have no significant effect on job satisfaction but they have significant effect on performance. Job satisfaction has no significant effect on job performance and is not a mediating variable because the direct influence of all independent variables (supervision, job relations, compensation) on the dependent variable (job performance) is greater than the indirect effect through job satisfaction.
\end{abstract}

Keywords: compensation, job performance, job relations, job satisfaction, supervision

\section{INTRODUCTION}

According to Molengraaff, company is activities that is done continuously to produce goods or services for trading, distributing, or making agreements (Purwosutjipto, 2003). In its activities, the company relies on five types of economic resources known as 5Ms (men, money, material, market and method). Men or humans take a role as laborers producing goods and consumers of goods or services produced. Money is a vital element that creates a number of company capitals to buy goods then processed into other goods for gaining maximum profit. Company materials or goods are important factor in supporting productive activities. Market is where the company sells its products. Method or how to run a company 
in the form of productive ideas and initiatives determines the choice of strategic steps, minimizes risks (Hasibuan, 2016).

Men (humans) become the main factor in the overall production process of the company because humans are the actors of all the company's production activities. Therefore, the development of human resources is a mandatory if the company wants to survive, grow, and get maximum profit. Companies can develop their human resources through building job satisfaction for the people who work in the company. By doing this, the company can expect their workers to work optimally and deliver their best for the progress of the company. Indrawijaya in Ibrahim (2012) outlined the reasons of importance for the company to pay attention on employee's job satisfaction: (a) workers use most of their waking time for work than for joy; (b) work can cause psychological impact and the feeling obtained from job satisfaction is expected can be brought to the work environment; (c) Palmore's study (1969) in the United States resulted that people who were satisfied with their work tended to live longer than people who do not their work. Job satisfaction has recently become a crucial problem in the Asia Pacific region. The survey issued by TinyPulse (2017) stated that twothirds of employees have problems with their job satisfaction.

$\mathrm{CV}$. Aliansyah is a company that distributes agricultural supplements and livestocks in the region of South Pati in particularly the village of Pecangaan, Winong, Pati, Central Java. Even though supervision in CV. Aliansyah has been well, but inconsistent achievements of the supervision still become the problem for the management. Work relations between employees have also already well established. However, there are still gaps between senior and junior and the lack of communication between employees makes a problem for the employees. Compensation offered by the company has also been increasing each year. The other problem is that there are still employees who are absent without permission. 
This study aims to determine the effect of supervision, job relations, compensation on job satisfaction and its impact on job performance of the employees of CV. Aliansyah.

\section{LITERATURE REVIEW AND DEVELOPMENT OF HYPOTHESES}

\section{Job Satisfaction}

According to Wexley and Yukl in As'ad (1981), job satisfaction is "the way an employee feels about his job." Simamora (1997) defines job satisfaction as a condition that has and contains likes and dislikes. Robbins and Judge (2015) defined job satisfaction as a general attitude of a person towards his job, where in his job individuals are required to interact with colleagues and superiors, follow the rules and organizational policies, and meet performance standards. Hasibuan (2002) stated that job satisfaction is the emotional condition of workers who are pleasant and love their jobs.

\section{Supervision}

Manullang and Marihot in Samian (2013) defined supervision as the process of doing works on everything that has been done and evaluating it. Siagian (2002) said that supervision is the process of observation of the implementation of all company activities with the aim to ensuring that all works being carried out are running well and in accordance with the plan previously determined. Handoko (2000) noted that supervision is way and tool that is applied to guarantee that implementation of the plan goes according to the planning.

\section{Job Relations}

In the narrow sense, job relations are the interaction between one person and another in a work situation. While the work relationship in the broadest sense is the interaction between one person and another towards a situation and working conditions that can provide motivation for them to work together productively and satisfactoryly for economically, psychologically and socially achieving organizational goals (Siagian, 2000). Sedarmayanti in 
Suwondo and Sutanto (2015), job relations is a non-physical work environment in terms of all circumstances that occur and relate to work relationships with superiors and fellow coworkers or with subordinates.

\section{Compensation}

According to Hasibuan (2002), compensation is all incomes in the form of money, which include salaries, wages, and benefits received by workers as remuneration for their contributions to responsibility to the corporate. Rivai in Fidiyanto, Warso, and Fathoni (2018) noted that compensation is financial wages and intangible services and benefits received by workers as part of the employment relationship.

\section{Job Performance}

Bernard and Russel in Maizar (2017) stated that job performance is the unit abilities and efforts made by a person and can be measured from the work of the person. Meanwhile Mangkunegara in Can (2016) defined job performance as the result of the work of an employee who can be calculated in quality and quantity in carrying out their duties and responsibilities within the organization.

\section{Supervision and Job Satisfaction}

Supervision is the discovery and application of methods and tools to ensure that plans have been carried out in accordance with what has been determined (Handoko, 2000). Supervision is positive if it is done by finding out the way the organization's objectives can be achieved. This means that all employees are involved in finding the best way to achieve organizational goals. By involving them in planning supervision, a sense of respect will be developed which is one of the hierarchies of human needs that will make satisfaction in work.

Rismayana's (2014) study on 81 respondents of the employee of the Department of Transportation Communication and Information of East Kutai Regency found that supervision had an effect on job satisfaction. Likewise, Yunita's research (2016) proves that 
supervision partially has a significant positive effect on job satisfaction. Thus, the researcher formulates the hypothesis:

H1: Supervision has a significant positive effect on Job Satisfaction.

\section{Job Relations and Job Satisfaction}

Robbins and Judge (2015) said that the work environment of an employee greatly influences the level of work satisfaction. Sedarmayanti in Suwondo and Sutanto (2015) outlined the type of work environment that is divided into two parts: physical work environment and non-physical work environment. Companies should not ignore the nonphysical working environment conditions of employees. That is because the non-physical work environment is related to the psychological side of the employee which affects whether he is satisfied or not, happy or hateful with his job. The non-physical work environment is defined as the overall condition that occurs in relation to the relationship between co-workers, or between superiors and subordinates.

Research of Rahmawati and Rumita (2015) on 96 respondents from PT. Indotama Omicron Kahar resulted in that job relations have an effect on job satisfaction. Thus, the researcher formulates the hypothesis:

H2: Job Relations have a significant positive effect on Job Satisfaction.

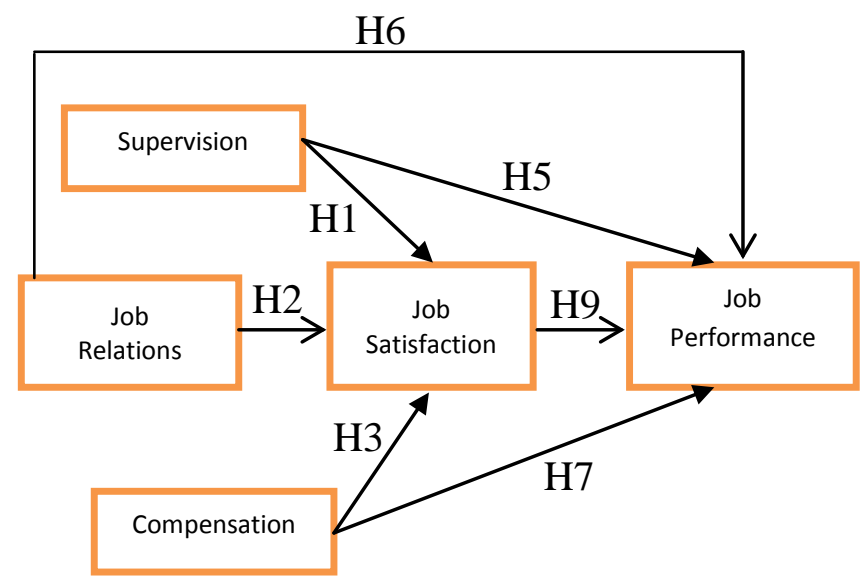

Figure 1

Research Framework 


\section{Compensation and Job Satisfaction}

Handoko (2000) explained that a department could increase employees' job satisfaction through compensation. Nitisemito (1991) divided compensation in two forms: direct (such as salary, wages, bonuses, and commissions) and indirect (such as insurance, health benefits, facilities for employees that include the availability of uniforms, parking lots and other costs). Direct and indirect financial compensation expectedly facilitates job satisfaction for employees so that employees are empowered to strive for all their efforts for the success of the company. The employees who are satisfied with the results obtained from the company will also satisfy with their work. Fair and satisfying financial compensation can be a driving factor for employees to increase their job satisfaction.

Ahmudi, et al. (2018) research on 50 respondents from PT. XYZ in Semarang found that compensation affected job satisfaction. Kurniawan's research (2016) on 134 employees of PT. Samtraco Utama Samarinda also resulted in evidence that receives compensation has a positive effect on job satisfaction. Therefore, the researcher formulates the hypothesis:

H3: Compensation has a significant positive effect on Job Satisfaction.

\section{Supervision and Job Performance}

Supervision, which means a process to observe the implementation of all organizational activities, aims at ensuring that all work being carried out goes according to a predetermined plan (Siagian, 2000). This requires a supervisor to be able to observe the process of activities carried out by employees. Supervisors are required to be able to read and correct if there are deviations that occur during the course of the implementation of the activity. Employees as the parties who are assessed and measured by their work must feel comfortable and not feel monitored at all times. Employees must be educated to feel that their duties are their responsibility, the results of which will be enjoyed together. This can work well if the employee can understand and accept methods developed by the supervisor. By 
means of supervision that makes employees aware of their duties and responsibilities, supervision of a supervisor will increase the employee's performance.

Norbaiti's research (2013) on 46 respondents of the staff of the Department of Industry and Trade of South Kalimantan Province got evidence that supervision had an effect on job performance. Sami'an and Aprilian (2013) examined the respondents of 114 railroad employees found that supervision influenced job performance. Therefore, the researcher formulates the hypothesis:

H5: Supervision has a significant positive effect on Job Performance.

\section{Job Relations and Job Performance}

Sedarmayanti in Suwondo and Sutanto (2015) said that job relations are non-physical work environments, which are defined as all conditions that occur in relation to the relationships between superiors or fellow co-workers or subordinates. A boss who is friendly, is sociable, has willing to listen, and is good will make subordinates feel protected. Relationships within and outside the work that exists between employees at the same level also make the psychological condition of employees is stable. Employees who help each other at work, problems are resolved quickly, and a sense of sharing workloads will create a conducive working atmosphere. Two capitals of superior-subordinate relationships and relationships among co-workers will make employee performance increase.

Laniwidyanti’s (2010) research on 109 respondents of the employees of Bank BCA Malang found that job relations had a significant positive effect on job performance. Thus, the researcher formulates the hypothesis:

H6: Job Relations have a significant positive effect on Job Performance.

\section{Compensation and Job Performance}

According to Hasibuan (2016), compensation which is the company's remuneration for the work of employees can be expected to influence the work results or output the 
employees will produce. The cause is a person's basic desire in fulfilling his life needs, both his personal needs and the needs of the people under his responsibility (family). This basic rule follows Maslow's Theory of Needs, which the management must understand in determining compensations the company must give to employees.

Companies must be observant and understand the standard needs of employees and their families according to the demographics where the company locates. With adequate compensation, employees will feel safe to work with the company and will feel that the amount of the compensation received is in accordance to the size of the work they do.

Maizar's research (2017) on 30 respondents from PT. Perkebunan Nusantara VI got the results that compensation had an effect on job performance. Research by Zulkarnaen and Herlina (2018) at 58 respondents of PT. Pranata Jaya Abadi Banjaran also proves that compensation affected the job performance of employees in the operational section. Thus, the researcher formulates the hypothesis:

H7: Compensation has a significant positive effect on Job Performance.

\section{Job Satisfaction and Job Performance}

Mangkunegara in Brahmasari (2008) stated that there are several factors influence job satisfaction covering internal factors (in employees) and external factors (outside of employees). When these factors are satisfied, employee's job satisfaction will be high. Physical and psychological conditions available for performing works and carrying out tasks are supported by the conditions of the place and a satisfying work environment makes employees to become satisfied at work.

In line with that, Nawawi (1998) also discussed that internal factors and external factors are the factors that can influence performance. Strong physical and mental conditions, healthy organization, and high self-ability improve performance. All three will be the energy for working and producing high work output. 
Research by Handayaningrum, Astuti, Prasetya (2016) on 66 employees of PDAM Kota Malang got evidence that job satisfaction had an effect on employee performance. Therefore, the researcher formulates the hypothesis:

H9: Job Satisfaction has a significant positive effect on Job Performance

\section{METHODOLOGY}

This research is explanatory research using a quantitative approach. The research was conducted at CV. Aliansyah in the village of Pecangaan, Winong, Pati. The population of this research is CV.Aliansyah's employees amounted of 78 peoples. The sampling method used Tabachnick and Fiddel's that resulted in a sample of 74 people. Because the population is homogeneous, all population members are used as research samples.

The primary data of this study was collected using questionnaires to CV. Aliansyah's employees. The goal was to get information from the respondents about their knowledge on the research problems. Five-point Likert scale was to formulate the questions. The validity and reliability tests were respectively Pearson Product Moment correlation and Cronbach’s Alpha.

The classic assumption tests were to find out whether the regression model fits the classical assumptions. In this case, the assumption test covered multicollinearity test, autocorrelation test, normality test. The regression analysis was multiple linear regression analysis and path analysis.

\section{RESULTS AND DISCUSSION}

Validity test was to test if each independent variable accurately explains dependent variable of job satisfaction. The variable of supervision (X1) consists of 11 questions, variable of job relations (X2) consists of 12 questions, compensation (X3) consists of 8 
questions, job satisfaction (Y1) consists of 10 questions, and job performance (Y2) consists of 12 questions.

Using Pearson Product Moment, the item was considered valid if the correlation coefficient $r>0.227$. The results presented in table 1 show that all items of all variables are valid, because the value of each item was greater than 0.227 .

Table 1

Result of Validity Test

\begin{tabular}{|c|c|c|c|}
\hline Variable & Question & r Result & Decision \\
\hline \multirow{11}{*}{ Supervision } & X1-1 & 0,486 & Valid \\
\hline & $\mathrm{X} 1-2$ & 0,409 & Valid \\
\hline & $\mathrm{X} 1-3$ & 0,563 & Valid \\
\hline & $\mathrm{X} 1-4$ & 0,621 & Valid \\
\hline & $\mathrm{X} 1-5$ & 0,554 & Valid \\
\hline & X1-6 & 0,602 & Valid \\
\hline & X1-7 & 0,529 & Valid \\
\hline & $\mathrm{X} 1-8$ & 0,463 & Valid \\
\hline & X1-9 & 0,540 & Valid \\
\hline & X1-10 & 0,447 & Valid \\
\hline & X1-11 & 0,537 & Valid \\
\hline \multirow[t]{12}{*}{ Job Relations } & X2-1 & 0,439 & Valid \\
\hline & $\mathrm{X} 2-2$ & 0,412 & Valid \\
\hline & $\mathrm{X} 2-3$ & 0,520 & Valid \\
\hline & $\mathrm{X} 2-4$ & 0,404 & Valid \\
\hline & X2-5 & 0,585 & Valid \\
\hline & X2-6 & 0,478 & Valid \\
\hline & $\mathrm{X} 2-7$ & 0,482 & Valid \\
\hline & $\mathrm{X} 2-8$ & 0,557 & Valid \\
\hline & X2-9 & 0,431 & Valid \\
\hline & $\mathrm{X} 2-10$ & 0,477 & Valid \\
\hline & $\mathrm{X} 2-11$ & 0,555 & Valid \\
\hline & $\mathrm{X} 2-12$ & 0,478 & Valid \\
\hline \multirow[t]{8}{*}{ Compensation } & X3-1 & 0,479 & Valid \\
\hline & X3-2 & 0,504 & Valid \\
\hline & X3-3 & 0,646 & Valid \\
\hline & X3-4 & 0,491 & Valid \\
\hline & X3-5 & 0,489 & Valid \\
\hline & X3-6 & 0,697 & Valid \\
\hline & X3-7 & 0,552 & Valid \\
\hline & X3-8 & 0,630 & Valid \\
\hline
\end{tabular}




\begin{tabular}{|c|c|c|c|}
\hline Variable & Question & r Result & Decision \\
\hline \multirow{10}{*}{ Job Satisfaction } & Y1-1 & 0,542 & Valid \\
\hline & Y1-2 & 0,548 & Valid \\
\hline & Y1-3 & 0,627 & Valid \\
\hline & Y1-4 & 0,637 & Valid \\
\hline & Y1-5 & 0,554 & Valid \\
\hline & Y1-6 & 0,651 & Valid \\
\hline & Y1-7 & 0,611 & Valid \\
\hline & Y1-8 & 0,533 & Valid \\
\hline & Y1-9 & 0,489 & Valid \\
\hline & Y1-10 & 0,563 & Valid \\
\hline \multirow[t]{12}{*}{ Job Performance } & Y2-1 & 0,240 & Valid \\
\hline & Y2-2 & 0,276 & Valid \\
\hline & $\mathrm{Y} 2-3$ & 0,503 & Valid \\
\hline & Y2-4 & 0,545 & Valid \\
\hline & Y2-5 & 0,570 & Valid \\
\hline & Y2-6 & 0,525 & Valid \\
\hline & Y2-7 & 0,510 & Valid \\
\hline & Y2-8 & 0,501 & Valid \\
\hline & Y2-9 & 0,404 & Valid \\
\hline & Y2-10 & 0,446 & Valid \\
\hline & Y2-11 & 0,411 & Valid \\
\hline & Y2-12 & 0,397 & Valid \\
\hline
\end{tabular}

Based on the results of the validity test, the value of Cronbach's Alpha of supervision (X1), job relations (X2), compensation (X3), job satisfaction (Y1) and job performance (Y2) is greater than 0.6, meaning that the variables used in this study are reliable. According to Ghozali (2011), the research instrument is said to be reliable if it has Alpha Cronbach's coefficient value above 0.6.

Table2

\section{Result of Reliability Test}

\begin{tabular}{|l|r|r|}
\hline \multicolumn{1}{|c|}{ Variable } & $\begin{array}{c}\text { Cronbach's } \\
\text { Alpha }\end{array}$ & Reliability \\
\hline Job Satisfaction & 0,777 & Reliable \\
\hline Job Performance & 0,632 & Reliable \\
\hline Supervision & 0,733 & Reliable \\
\hline Work Relations & 0,706 & Reliable \\
\hline Compensation & 0,690 & Reliable \\
\hline
\end{tabular}




\section{Classic Assumption Tests}

Because the correlation between variable is still below 95\%, it can be said that there is no serious multicollinearity.

Table 3

\section{Multicollinearity Test}

\begin{tabular}{|c|c|c|c|c|c|}
\hline \multicolumn{6}{|c|}{ Coefficient Correlations $^{\mathrm{a}}$} \\
\hline \multicolumn{3}{|c|}{ Model } & Compensation & Supervision & Job Relations \\
\hline \multirow[t]{6}{*}{1} & Correlations & Compensation & 1.000 & .047 & -.088 \\
\hline & & Supervision & .047 & 1.000 & -.188 \\
\hline & & Job Relations & -.088 & -.188 & 1.000 \\
\hline & Covariances & Compensation & .022 & .001 & -.002 \\
\hline & & Supervision & .001 & .017 & -.003 \\
\hline & & Job Relations & -.002 & -.003 & .016 \\
\hline
\end{tabular}

a. Dependent Variable: Job Satisfaction

Durbin Watson's value is 1,148 . Because the DW value is greater than 0 and less than the lower limit (dL), there is a positive autocorrelation in the regression model.

Table 4

\section{Autocorrelation Test}

\begin{tabular}{|l|r|r|r|r|r|}
\hline & Model Summary & \\
\hline Model & R & R Square & $\begin{array}{c}\text { Adjusted R } \\
\text { Square }\end{array}$ & $\begin{array}{c}\text { Std. Error of } \\
\text { the Estimate }\end{array}$ & $\begin{array}{c}\text { Durbin- } \\
\text { Watson }\end{array}$ \\
\hline 1 & $.162^{\mathrm{a}}$ & .026 & -.013 & 3.518 & 1.148 \\
\hline
\end{tabular}

a. Predictors: (Constant), compensation, supervision, job relations

b. Dependent Variable: job satisfaction

The histogram in figure 2(a) shows the skewness of the left and abnormal. The normal plot graph (figure 2(b)) shows that the points spread around the diagonal line, and the spread is far from the diagonal line. Both graphs show that the regression model violates the rules of normality assumption. 


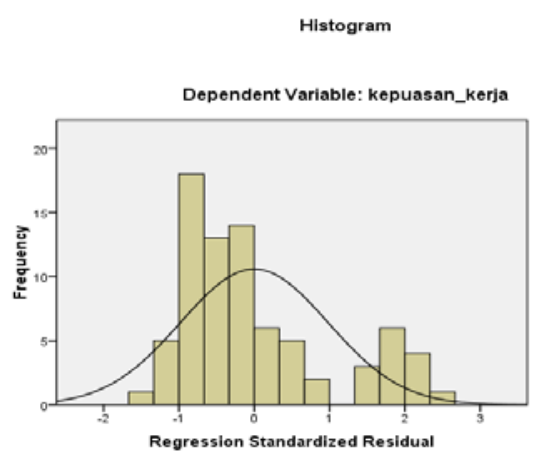

(a)

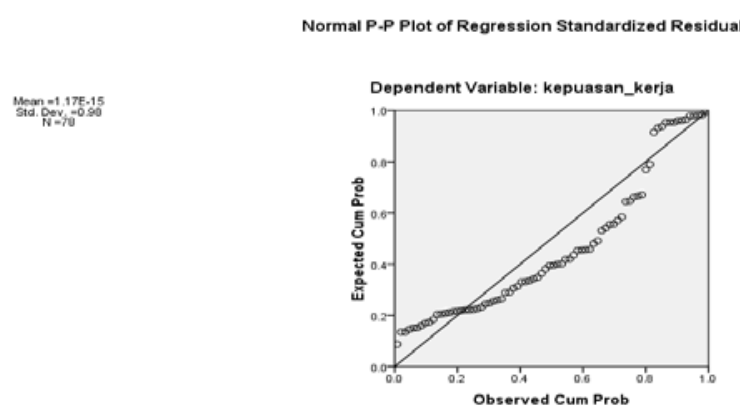

(b)

Figure 2

\section{Histogram and Normal Plot}

\section{Multiple Linear Regression Analysis}

The first regression on job satisfaction results in $\mathrm{Y}_{1}=27.188+0.130 \mathrm{X}_{1}+0.101 \mathrm{X}_{2}-$ $0,004 \mathrm{X}_{3}$. The calculated value of $\mathrm{t}$ for supervision is 0.995 with significance value of $0.323>$ $0.05(\alpha)$. It can be concluded that there is no significant effect of supervision on job satisfaction. Thus, Hypothesis 1, which states that supervision has a significant positive effect on job satisfaction, is rejected.

Table 5

\section{t Test Result on Job Satisfaction}

\begin{tabular}{|l|r|r|}
\hline & $\mathrm{t}$ & \multicolumn{1}{|c|}{ Sig. } \\
\hline Supervision & 0.995 & 0.323 \\
\hline Job relationship & 0.802 & 0.425 \\
\hline Compensation & -0.027 & 0.979 \\
\hline
\end{tabular}

The $t$ calculated value for the work relationship is 0.802 with a significance value of 0.425 , which $>\alpha(0.05)$. It can be concluded that there is no significant effect of job relations on job satisfaction of CV. Aliansyah's employees. Thus, Hypothesis 2, which states that the job relations has a significant positive effect on job satisfaction, is rejected.

The calculated value for compensation is -0.027 with a significance value of 0.979 . Because the significance value $>\alpha(0.05)$, it can be concluded that there is no significant 
effect of compensation on job satisfaction of CV. Aliansyah's employees. Thus, Hypothesis 3, which states that compensation has a significant positive effect on job satisfaction, is rejected.

Simultaneous test (F Test) results in 0.669 and significance 0.574 . Because the calculated $\mathrm{F}$ value is smaller than $\mathrm{F}$ table $0.669<2.73$ and the significance value is greater than 0.05 , it can be concluded that supervision, job relations, and compensation simultaneously do not influence job satisfaction significantly. Thus, Hypothesis 4, which states that supervision, job relations, compensation together have a significant effect on job satisfaction, is rejected.

The second regression on job performance results in $\mathrm{Y}_{2}=16.633+0.823 \mathrm{X}_{1}-$ $0.072 \mathrm{X}_{2}-0.092 \mathrm{X}_{3}$. The $\mathrm{t}$ test on supervision is 17.795 with a significance value of 0,000 . Due to the significance value of $0,000<\alpha(0.05)$, it can be concluded that there is a significant effect of supervision on the job performance of CV. Aliansyah's employees. Thus, Hypothesis 5, which states that supervision has a significant positive effect on job performance, is accepted.

\section{Table 6}

t Test Result on Job Performance

\begin{tabular}{|l|r|r|}
\hline & $\mathrm{t}$ & \multicolumn{2}{|c|}{ Sig. } \\
\hline Supervision & 17.795 & 0.000 \\
\hline Job relations & -1.613 & 0.111 \\
\hline Compensation & -1.737 & 0.087 \\
\hline
\end{tabular}

The t calculated value for job relations is $-1,613$ with a significance value of 0,111 . Due to the significance value of $0.111>\alpha(0.05)$, it can be concluded that there is no significant effect of job relations on the job performance of CV. Aliansyah's employees. Thus, Hypothesis 6, which states that job relations have a significant positive effect on job performance, is rejected. 
The t calculated value for compensation is -1.737 with a significance value of 0.087 . Due to the significance value of $0.087>\alpha(0.05)$, it can be concluded that there is no significant effect of compensation on the job performance of CV. Aliansyah's employees. Thus, Hypothesis 7, which states that compensation has a significant positive effect on job performance, is rejected.

Simultaneous test (F test) on job performance was 168,814 and significance 0,000. Because the value of $\mathrm{F}$ is greater than $\mathrm{F}$ table of 2.73 and the significance value is smaller than 0.005, the supervision, job relations, and compensation simultaneously have a significant effect on job performance. Thus, Hypothesis 8, which states that supervision, job relations, and compensation together have a significant effect on job performance, is accepted.

Regression of job satisfaction on job performance results in coefficient of 0.148 , meaning there is positive influence of job satisfaction on job perfomance. The t calculated value for job satisfaction on job performance is 1.612 with significance value of 0.111 . Due to the significance value of $0.111>\alpha(0.05)$, it can be concluded that there is significant effect of job satisfaction on the job performance of CV. Aliansyah's employees. Thus, Hypothesis 9, which states that job satisfaction has a significant positive effect on job performance, is rejected.

From the results of all mediation tests, all independent variables (Supervision, Job Relations, Compensation) were found to have no significant effect on mediator variables (Job Satisfaction); all values of the direct effect of the independent variable on performance are greater than the value of the influence of independent variables through mediator variables on performance. Thus, Hypothesis 10, which states that job ssatisfaction mediates supervision, job relations, compensation for job performance, is rejected. 


\section{Table 7}

\section{Summary of the Hypothesis}

\begin{tabular}{|l|l|l|}
\hline Hypothesis & \multicolumn{1}{|c|}{ Statement } & \multicolumn{1}{|c|}{ Decision } \\
\hline H1 & $\begin{array}{l}\text { Supervision has a significant positive effect on job } \\
\text { satisfaction }\end{array}$ & Rejected \\
\hline H2 & $\begin{array}{l}\text { Job Relations has a significant positive effect on } \\
\text { job satisfaction }\end{array}$ & Rejected \\
\hline H3 & $\begin{array}{l}\text { Compensation has a significant positive effect on } \\
\text { job satisfaction }\end{array}$ & Rejected \\
\hline H4 & $\begin{array}{l}\text { Supervision, Job Relations, Compensation together } \\
\text { have a significant effect on Job Satisfaction }\end{array}$ & Rejected \\
\hline H5 & $\begin{array}{l}\text { Supervision has a significant positive effect on job } \\
\text { performance }\end{array}$ & Accepted \\
\hline H6 & $\begin{array}{l}\text { Job Relations has a significant positive effect on } \\
\text { job satisfaction }\end{array}$ & Rejected \\
\hline H7 & $\begin{array}{l}\text { Compensation has a significant positive effect on } \\
\text { job satisfaction }\end{array}$ & Rejected \\
\hline H8 & $\begin{array}{l}\text { Supervision, Job Relations, Compensation together } \\
\text { have a significant effect on Performance }\end{array}$ & Accepted \\
\hline H9 & $\begin{array}{l}\text { Job Satisfaction has a significant positive effect on } \\
\text { Job Performance }\end{array}$ & Rejected \\
\hline H10 & $\begin{array}{l}\text { Job Satisfaction mediates Supervision, Job } \\
\text { Relations, Compensation for Job Performance }\end{array}$ & Rejected \\
\hline
\end{tabular}

\section{Path Analysis}

The path analysis results in three following equations:

Regression Equation 1: $\mathrm{Y}_{1}=0,13 \mathrm{X}_{1}+0,10 \mathrm{X}_{2}-0,004 \mathrm{X}_{3}$

$$
\mathrm{t}(1.00) \quad(0.80) \quad(0.027)
$$

The effect of supervision, job relations, and compensation on job satisfaction is respectively not significant (t-value $>0.05$ ). The contribution of supervision, job relations, and compensation on the variance of job satisfaction is only $2.6 \%$, meaning $97.4 \%$ is influenced by other variables.

Regression equation 2: $\mathrm{Y}_{2}=0,82 \mathrm{X}_{1}-0,072 \mathrm{X}_{2}-0,092 \mathrm{X}_{3}$

$$
\text { t (17.79) (1.61) (1.74) }
$$

The effect of supervision, job relations, and compensation on job performance is also respectively not significant (t-value $>0.05$ ). Supervision, job relations, and compensation 
contributes to the variance of job performance as much as $82 \%$ or $18 \%$ is influenced by other variables.

Regression Equation 3: $\mathrm{Y}_{2}=0,058 \mathrm{Y}_{1}$

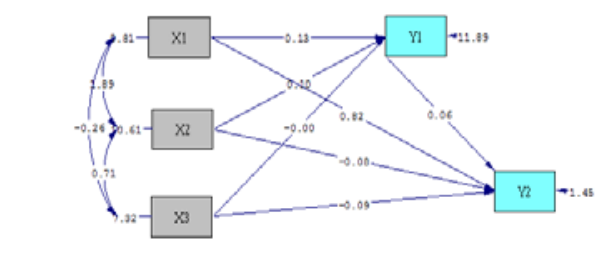

Figure 3

Path Analysis Model

\section{Discussion}

\section{Effect of Supervision on Job Satisfaction}

The respondent's response on the items of supervision indicates that the employees like the attitude of the leader who helped and provided a direct solution to the problems they face at work. However, they did not correct errors quickly when they were doing so. This shows that employees were less active in improving themselves even though they were able to finish their work on time. Employees preferred the attitude of the leader or boss who was active when they saw irregularities in the course of the work rather than corrected mistakes with their awareness. This result supports Norbaiti's (2013) study in which supervision has no effect on job satisfaction and thus it rejects Rismayana's (2014) study.

\section{Effect of Job Relations on Job Satisfaction}

The average work period of employees which was 1-2 years has caused their working relationship was not strong. This means that the well-established working relationship between fellow co-workers can still be bad because of certain things in relation to their recent work period. The employees also felt that they were not given the freedom to argue that 
cretaed a feeling of dissatisfaction in carrying out their work duties. This influenced the significance of the work relationship to job satisfaction. This study supports the Thyophoida's (2014) study that job relations have no effect on job satisfaction and reject the research of Rahmawati and Rumita (2015).

\section{Effect of Compensation on Job Satisfaction}

On average the respondents stated that compensation did not give them job satisfaction since the compensation received by the employees could only increase if they were able to get a bonus, while their salary remained the same. The higher compensation caused lower job satisfaction because the employees had work harder to get additional compensation. The employees who were mostly teenagers was another cause in which compensation was not their main goal for working. They were more likely to seek work experience, build self-esteem, and learn to earn their own income. This study supports the research of Handayaningrum, Astuti, Prasetya (2016) stating that compensation does not have a significant effect on job satisfaction and thus rejects the research of Ahmudi, et al (2018).

\section{Effect of Supervision, Job Relations, Compensation on Job Satisfaction}

From the results of the regression analysis show that supervision and job relations have a positive effect on job satisfaction while compensation has a negative effect on job satisfaction. Simultaneously, supervision, job relations, compensation do not significantly influence the job satisfaction variable.

Among the three variables, supervision has the greatest influence on employees’ job satisfaction. The employees felt that the leaders who wanted to help their difficulties when conducting supervision gave job satisfaction. Job relations occupied the second position since the employees who were relatively new led them to have close working relationship with others. Compensation was on the third since the main purpose to work of the employees who were mostly teenagers was not compensation but self-pride and social status. 


\section{Effects of Supervision on Job Performance}

The regression results indicate that supervision has a positive and significant effect on job performance. This means that supervision that has been carried out by the company through the leaders and the coordinators influences employees' performance significantly. Supervision is importantly necessary since most of the employees were still teenagers and late adolescents. Supervision was to monitor and control the character of adolescent workers who were still unstable and who needed guidance from superiors and leaders. This study supports Norbaiti's (2013) research that concluded if supervision influences job performance and rejects Rosdiana and Indriasih’s (2016) research.

\section{Effect of Job Relations on Job Performance}

The regression results indicate that the job relations have no significant negative effect on job performance. This means that they will work together on jobs prioritized by the company even though they were still doing their own tasks and this reduced their performance in their own works. This study supports Rosita's (2014) research that job relations do not affect job performance and reject the research of Lani Widyanti (2010).

\section{Effect of Compensation on Job Performance}

The regression results indicate that compensation has a negative and not significant effect on job performance. The provision of compensation that prioritizes bonuses brought consequences to the employees who must work harder to get bigger compensation and who must sacrifice their performance. Variety types of compensation in the company such as bonuses and incentives were the cause since they were given to employees after completing heavy and many workloads. Some respondents who were teens and unmarried had made compensation has negative and insignificant effect on their performance in the company. This study supports the research of Ahmudi et al (2018) that resulted in compensation has no effect on job performance and rejects Maizar's research (2017). 


\section{Effect of Supervision, Job Relations, Compensation on Job Performance}

Among the variables, supervision has the greatest influence on job performance. The supervisor that were able to move all employees to work together in job relations also relate to compensation. That is the cause of supervision, job relations, and compensation to have a significant effect on the performance of CV. Aliansyah’s employees.

\section{Effect of Job Satisfaction on Job Performance}

The regression results indicate that job satisfaction has positive and not significant effect on job performance. Comfort and helpful co-workers were not enough to influence job performance. The desire of employees to listen to their co-workers' opinions was low and this made job satisfaction was not important for their job performance. This study supports Ahmudi's (2018) research stating that job satisfaction has no effect on job performance and rejects Handayaningrum, Astuti, Prasetya’s (2016) research.

\section{Effects of Mediation of Job Satisfaction on Supervision, Job Relations, Compensation for}

\section{Job Performance}

The path analysis showed that job satisfaction did not mediate supervision, job relations, and compensation to have effect on job performance of CV. Aliansyah's employees. This happened because of the low value of the influence of supervision, job relations, and compensation on job satisfaction. On average, the employee were not satisfied with the boss who did not want to hear their opinions and with promotion opportunity that was unavailable in the type of compensation even though the employees showed their agreement on the statement that the promotion would increase their income. This study supports the research of Ahmudi et al's (2018) and rejects Hidayah's (2016) study.

\section{CONCLUSIONS}

Based on the analysis, it can be concluded as follows: 
1) Supervision, job relations, compensation partially and simultaneously have no significant effect on job satisfaction.

2) Partially, supervision has a significant effect on job performance

3) Job relations and compensation partially have no significant effect on job performance

4) Supervision, job relations, and compensation simultaneously have a significant effect on job performance

5) job satisfaction partially has no significant effect on job performance

6) Job satisfaction does not mediate supervision, job relations, and compensation for job performance.

\section{REFERENCES}

Ahmudi, et al. (2018, March). Pengaruh Motivasi Kerja, Kompetensi, Dan Kompensasi Terhadap Kepuasan Kerja Dan Dampaknya Terhadap Kinerja Karyawan (Studi Kasus PT XYZ). Article presented at the National Seminar of IENACO, Surakarta

Arikunto, S. (2006). Prosedur Penelitian Suatu Pendekatan Praktik. Jakarta: Rineka Cipta

As’ad, M. (1981). Psikologi Industri. Yogyakarta: Liberty

Brahmasari and Suprayetno. (2008). Pengaruh Motivasi Kerja, Kepemimpinan dan Budaya Organisasi Terhadap Kepuasan Kerja Karyawan serta Dampaknya pada Kinerja Perusahaan (Studi kasus pada PT. Pei Hai International Wiratama Indonesia). Jurnal Manajemen dan Kewirausahaan, 2, 124-135

Can and Yasri. (2016). Pengaruh Motivasi Kerja, Kepuasan Kerja Dan Komitmen Organisasi Terhadap Kinerja Karyawan Pada Bank Nagari. Jurnal Riset Manajemen Bisnis dan Publik, $1,1-26$

Fidiyanto et al. (2018). Analisis Pengaruh Organizational Citizenship Behavior Dan Kompensasi Terhadap Kinerja Karyawan (Studi pada PT. Hop Lun Indonesia Kab. Semarang). Journal of Management, 4, 1-17

Ghozali, I. (2011). Aplikasi Analisis Multivariate Dengan Program IBM SPSS 19 edisi 5. Semarang: Badan Penerbit Universitas Diponegoro

Handayaningrum et al. (2016). Faktor-Faktor Yang Mempengaruhi Kepuasan Kerja Dan Kinerja Karyawan (Studi pada Karyawan PDAM Kota Malang). Jurnal Administrasi Bisnis, $1,141-149$

Handoko,TH. (2000). Manajemen Edisi 2. Yogyakarta: BPFE

Hariandja, MTE. (2002). Manajemen Sumber Daya Manusia. Jakarta:GRASINDO

Hasibuan, SPM. (2002). Manajemen Sumber Daya Manusia. Jakarta:Bumi Aksara 
Hasibuan, SPM. (2016). Manajemen: Dasar, Pengertian, dan Masalah. Jakarta: Bumi Aksara

Hidayah and Aisyah. (2016). Pengaruh Kompensasi Terhadap Kinerja Karyawan Dengan Kepuasan Kerja Sebagai Variabel Intervening (Studi Kasus Pada Karyawan Bagian Keuangan Dan Akuntansi UNY). Jurnal Profita, 4, 1-12

Ibrahim, TC.(2012). Pengaruh Kepuasan Kerja Terhadap Kinerja Pegawai Pada Inspektorat Kabupaten Aceh Utara. Unpublished master thesis, Terbuka University, Jakarta

Laniwidyanti et al. (2010). Pengaruh Hubungan Kerja, Pengalaman Kerja Dan Motivasi Kerja Terhadap Kinerja Karyawan Bank Central Asia (BCA) Cabang Borobudur, Malang. Jurnal WACANA, 2, 214-226

Luthans, F. (2006). Perilaku Organisasi. Yogyakarta: Andi

Maizar, J. (2017). Pengaruh Motivasi, Kompetensi Kerja Dan Kompensasi Terhadap Kinerja Karyawan Pada PT. Perkebunan Nusantara VI (Persero) Pasaman Barat. Jurnal EKOBISTEK, 2, 218-239

Nawawi, H. (1998). Manajemen Sumber Daya Manusia. Yogyakarta: Gadjah Mada University Press

Nitisemito, AS. (1991). Manajemen Personalia. Jakarta: Ghalia Indonesia

Norbaiti. (2013). Pengaruh Pengawasan, Kepemimpinan, Dan Pelatihan Terhadap Kinerja Dan Kepuasan Kerja Pegawai Dinas Perindustrian Dan Perdagangan Provinsi Kalimantan Selatan. Jurnal SPREAD, 2, 125-136

Pangarso and Ramadhyanti (2015). Pengaruh Lingkungan Kerja Non Fisik Terhadap Kepuasan Kerja Dosen Tetap Studi Pada Fakultas Komunikasi Dan Bisnis Universitas Telkom Bandung. Jurnal KINERJA, 1, 172-191

Purwosutjipto, H. (2003). Pengertian Pokok Hukum Dagang Indonesia. Jakarta: Djambatan

Rahmawati and Rumita (2015). Analisis Pengaruh Motivasi, Reward Dan Hubungan Kerja Terhadap Kepuasan Kerja (Studi Kasus PT Indotama Omicron Kahar). Industrial Enginering Online Journal, 1, 1-14

Rismayana et al. (2014). Faktor - Faktor Yang Berpengaruh Terhadap Tingkat Kepuasan Kerja Pegawai Pada Dinas Perhubungan Komunikasi dan Informatika Kabupaten Kutai Timur. Jurnal Administrative Reform, 2, 14-25

Robbins and Judge (2015). Perilaku Organisasi .Jakarta: Salemba Empat

Rosdiana and Indriasih.(2016).Pengaruh Lingkungan Kerja, Pengawasan, Kompetensi Dan Motivasi Terhadap Kinerja Dengan Variabel Kompensasi Sebagai Variabel Intervening Pada Pegawai Dishubkominfo Kota Tegal. Jurnal MULTIPLIER, 1, 57-65 
Rosita,SRY.(2014).Pengaruh Hubungan Kerja Dan Lingkungan Kerja Terhadap Kinerja Pegawai Negeri Sipil Di Bagian Keuangan Universitas Jambi. Jurnal Manajemen Terapan dan Keuangan, 2, 523-532

Sami'an, AE. (2013). Pengaruh Kepemimpinan Dan Pengawasan Terhadap Kinerja Karyawan PT Kereta Api Indonesia (Persero) Di Kantor Daop IV Semarang. Jurnal Pendidikan Ilmu Sosial, 1, 10-14

Siagian,SP. (2000). Fungsi-Fungsi Manajerial. Jakarta: Bumi Aksara

Siagian, SP. (2002). Manajemen Sumber Daya Manusia. Jakarta: Bumi Aksara

Simamora, H. (1997). Manajemen Sumber Daya Manusia Edisi Kedua. Yogyakarta: Badan Penebitan STIE YKPN

SINDONews. $\quad$ (2017, $\quad$ February). $\quad$ Survey. https://ekbis.sindonews.com/read/1179556/35/survei-karyawan-di-asia-pasifik-tidak-bahagiadi-tempat-kerja-1486983935

Sudira and Sudarma (2014). Pengaruh Hubungan Kerja, Komunikasi, dan Tingkat Kesejahteraan terhadap Kinerja Karyawan pada Perusahaan PT. BPR Sari Dananiaga Tabanan. Jurnal Penelitian Manajemen, 1300-1310

Suwondo and Sutanto.(2015). Hubungan Lingkungan Kerja, Disiplin Kerja, Dan Kinerja Karyawan. Jurnal Manajemen dan kewirausahaan, 2, 135-144

Thyophoida. (2014). Pengaruh Budaya Organisasi, Hubungan Kerja, Lingkungan Kerja, Kepemimpinan Dan Kompensasi Terhadap Kepuasan Kerja. Jurnal Bisnis Perspektif, 2, 98110

Wibowo, LAH (2017). Employee Engagement: Antecendent \& Pengaruhnya pada Kinerja Karyawan UNIKA Soegijapranata Semarang. Unpublished master thesis, Soegijapranata Catholic University 